\title{
Lip and Oral Cavity Cancer pN2 TNM Finding v8
}

National Cancer Institute

\section{Source}

National Cancer Institute. Lip and Oral Cavity Cancer pN2 TNM Finding v8. NCI

Thesaurus. Code C132705.

Lip and oral cavity cancer with metastasis in a single ipsilateral lymph node, $3 \mathrm{~cm}$ or smaller in greatest dimension and $\mathrm{ENE}(+)$; or larger than $3 \mathrm{~cm}$ but not larger than $6 \mathrm{~cm}$ in greatest dimension and ENE (-); or metastases in multiple ipsilateral lymph nodes, none larger than $6 \mathrm{~cm}$ in greatest dimension and $\mathrm{ENE}(-)$; or metastases in bilateral or contralateral lymph nodes, none larger than $6 \mathrm{~cm}$ in greatest dimension, ENE(-). (from AJCC 8th Ed.) 